\title{
Nomenclature of the subgenera Moraxella and Branhamella and of the nine species included in these subgenera and proposal to modify Rule 34a of the Bacteriological Code (1990 Revision). Request for an Opinion
}

Ecole Nationale Vétérinaire, 23 chemin des Capelles, 31076 Toulouse cedex 3, France

\author{
J. P. Euzéby \\ Tel: +33 5611938 86. Fax: +33 5611939 75. e-mail: j.euzeby@envt.fr
}

Keywords: Moraxella, Branhamella, revived name, Bacteriological Code, Request for an Opinion
There are several problem areas in the nomenclature of the subgenera Moraxella and Branhamella and of species included into these two subgenera. The proposal to divide the genus Moraxella into two subgenera was effectively published by Bøvre (1979). This author proposed:

(1) the subgenus Moraxella with the following six species: Moraxella (subgen. Moraxella) lacunata, Moraxella (subgen. Moraxella) bovis, Moraxella (subgen. Moraxella) nonliquefaciens, Moraxella (subgen. Moraxella) osloensis, Moraxella (subgen. Moraxella) phenylpyruvica and Moraxella (subgen. Moraxella) atlantae;

(2) the subgenus Branhamella with the following three species Moraxella (subgen. Branhamella) catarrhalis, Moraxella (subgen. Branhamella) caviae and Moraxella (subgen. Branhamella) ovis.

These proposals were published in the October 1979 issue of the International Journal of Systematic Bac- teriology (Bøvre, 1979), which would qualify them for inclusion in the Approved Lists of Bacterial Names (Skerman et al., 1980, 1989) since Rule 24, Note 1 of the Bacteriological Code (1990 Revision) (Lapage et al., 1992) states 'Names validly published between 1 January 1978 and 1 January 1980 were included in the Approved Lists of Bacterial Names.' However, neither the two subgenera nor the nine species proposed by Bøvre (1979) were cited in the Approved Lists of Bacterial Names (Skerman et al., 1980, 1989) and these omissions are clearly not in accordance with Rule $24 \mathrm{a}$, Note 1.

Rule 24a, Note 1 also states that 'No further names will be added to the Approved Lists.' However, cases of omission from the Approved Lists of well-established names should be remedied by reviving the names under Rule 28a. For example, the species Spirochaeta litoralis, Spirochaeta zuelzerae and Spirochaeta aurantia inexplicably were not included in the Approved Lists and they have been revived by Canale-Parola (1980). 
The names proposed by Bøvre (1979) were never revived but the subgenera Branhamella and Moraxella were included in Validation List no. 15 (publication date, 16 July 1984) (Bøvre, 1984) as new subgenera with Moraxella (subgen. Branhamella) catarrhalis and Moraxella (subgen. Moraxella) lacunata as nomenclatural types, respectively. However, neither Moraxella (subgen. Branhamella) catarrhalis nor Moraxella (subgen. Moraxella) lacunata nor any of the other species proposed by Bøvre (1979) were included in this list.

In addition, Validation Lists are lists that validate bacterial names effectively published outside the $I n$ ternational Journal of Systematic Bacteriology or outside the International Journal of Systematic and Evolutionary Microbiology, not lists that validate names published in the International Journal of Systematic Bacteriology but inadvertently omitted from the Approved Lists.

Thereafter, all names proposed by Bøvre (1979) were included in the 'Index of the bacterial and yeast nomenclatural changes published in the International Journal of Systematic Bacteriology since the 1980 Approved Lists of Bacterial Names (1 January 1980 to 1 January 1985)' (Moore et al., 1985). In this Index, the valid publication date of these names is that of the paper published by Bøvre in 1979 except for the subgenus Moraxella for which the valid publication date is that of the Validation List no. 15. According to Rule 24a, 'Priority of publication dates from 1 January 1980 ', so it is not possible for a name to have a date of valid publication prior to 1 January 1980.

To avoid further confusion, I request that the subgenera Moraxella and Branhamella and the nine species proposed by Bøvre be revived and considered to be validly published in the Index published by Moore et al. (1985) and that the dates of valid publications be that of this Index (15 October 1985).

Another problem is the status of the species included in the subgenera Moraxella and Branhamella because the Bacteriological Code (1990 Revision) (Lapage et al., 1992) does not envisage the status of a species transferred into a subgenus. It is interesting to note that the same is true for a species transferred into a subspecies. I request that such species should be considered as new combinations and that the first sentence of Rule 34a be changed as follows:

"When an author transfers a species to another genus (Rule 41), or a species to another subgenus, or a subspecies to another species, or a species to another subspecies, then the author who makes the transfer should indicate the formation of the new combination by the addition to the citation of the abbreviation 'comb. nov.' (combinatio nova)."

If the Judicial Commission agrees with the above proposals, then the two subgenera and the nine species proposed by Bøvre should be cited as follows:
Moraxella (subgen. Branhamella) (ex Bøvre 1979) Bøvre 1985, subgen. nov., nom. rev. Type species: Moraxella (subgen. Branhamella Catlin 1970) catarrhalis (Frosch and Kolle 1896) (ex Bøvre 1979) Bøvre 1985.

Moraxella (subgen. Moraxella) (ex Bøvre 1979) Bøvre 1985, subgen. nov. Type species: Moraxella (subgen. Moraxella Lwoff 1939) lacunata (Eyre 1900) (ex Bøvre 1979) Bøvre 1985.

Moraxella (subgen. Branhamella Catlin 1970) catarrhalis (Frosch and Kolle 1896) (ex Bøvre 1979) Bøvre 1985, comb. nov., nom. rev. Type strain: strain Ne 11 $=$ NCTC $11020=$ ATCC 25238. Basonyms: Morax ella catarrhalis (Frosch and Kolle 1896) Henriksen and Bøvre 1968 (Approved Lists 1980), Branhamella catarrhalis (Frosch and Kolle 1896) Catlin 1970 (Approved Lists 1980).

Moraxella (subgen. Branhamella Catlin 1970) caviae (Pelczar 1953) (ex Bøvre 1979) Bøvre 1985, comb. nov., nom. rev. Type strain: strain GP $11=$ NCTC 10293 = ATCC 14659. Basonyms: Moraxella caviae (Pelczar 1953) Henriksen and Bøvre 1968 (Approved Lists 1980), Neisseria caviae Pelczar 1953 (Approved Lists 1980).

Moraxella (subgen. Branhamella Catlin 1970) ovis (Lindqvist 1960) (ex Bøvre 1979) Bøvre 1985, comb. nov., nom. rev. Type strain: strain 199/55 = NCTC $11227=$ ATCC 33078. Basonym: Moraxella ovis (Lindqvist 1960) Henriksen and Bøvre 1968 (Approved Lists 1980).

Moraxella (subgen. Moraxella Lwoff 1939) atlantae (Bøvre et al. 1976) (ex Bøvre 1979) Bøvre 1985, comb. nov., nom. rev. Type strain: strain $5118=$ NCTC $11091=$ ATCC 29525. Basonym: Moraxella atlantae Bøvre et al. 1976 (Approved Lists 1980).

Moraxella (subgen. Moraxella Lwoff 1939) bovis (Hauduroy et al. 1937) (ex Bøvre 1979) Bøvre 1985, comb. nov., nom. rev. Type strain: strain ATCC 10900. Basonym: Moraxella bovis (Hauduroy et al. 1937) Murray 1948 (Approved Lists 1980).

Moraxella (subgen. Moraxella Lwoff 1939) lacunata (Eyre 1900) (ex Bøvre 1979) Bøvre 1985, comb. nov., nom. rev. Type strain: strain Morax $260=$ NCTC $11011=$ ATCC 17967. Basonym: Moraxella lacunata (Eyre 1900) Lwoff 1939 (Approved Lists 1980).

Moraxella (subgen. Moraxella Lwoff 1939) nonliquefaciens (Scarlett 1916) (ex Bøvre 1979) Bøvre 1985, comb. nov., nom. rev. Type strain: strain 4663/62 = NCTC $10464=$ ATCC 19975. Basonym: Moraxella nonliquefaciens (Scarlett 1916) Lwoff 1939 (Approved Lists 1980).

Moraxella (subgen. Moraxella Lwoff 1939) osloensis (Bøvre and Henriksen 1967) (ex Bøvre 1979) Bøvre 1985, comb. nov., nom. rev. Type strain: strain A1920 $=$ NCTC $10465=$ ATCC 19976. Basonym: Morax - 
ella osloensis Bøvre and Henriksen 1967 (Approved Lists 1980).

Moraxella (subgen. Moraxella Lwoff 1939) phenylpyruvica (Bøvre and Henriksen 1967) (ex Bøvre 1979) Bøvre 1985, comb. nov., nom. rev. Type strain: strain $2863=$ NCTC $10526=$ ATCC 23333. Basonym: Moraxella phenylpyruvica Bøvre and Henriksen 1967 (Approved Lists 1980).

\section{References}

Bøvre, K. (1979). Proposal to divide the genus Moraxella Lwoff 1939 emend. Henriksen and Bøvre 1968 into two subgenera, subgenus Moraxella (Lwoff 1939) Bøvre 1979 and subgenus Branhamella (Catlin 1970) Bøvre 1979. Int J Syst Bacteriol 29, 403-406.

Bøvre, K. (1980). Branhamella subgen. nov. and Moraxella subgen. nov. In Validation of the Publication of New Names and
New Combinations Previously Effectively Published Outside the IJSB, List no. 15. Int J Syst Bacteriol 34, 355-357.

Canale-Parola, E. (1980). Revival of the names Spirochaeta litoralis, Spirochaeta zuelzerae, and Spirochaeta aurantia. Int J Syst Bacteriol 30, 594.

Lapage, S. P., Sneath, P. H. A., Lessel, E. F., Skerman, V. B. D., Seeliger, H. P. R. \& Clark, W. A. (editors) (1992). International Code of Nomenclature of Bacteria (1990 Revision). Bacteriological Code. Washington, DC: American Society for Microbiology.

Moore, W. E. C., Cato, E. P. \& Moore, L. V. H. (1985). Index of the bacterial and yeast nomenclatural changes published in the International Journal of Systematic Bacteriology since the 1980 Approved Lists of Bacterial Names (1 January 1980 to 1 January 1985). Int J Syst Bacteriol 35, 382-407.

Skerman, V. B. D., McGowan, V. \& Sneath, P. H. A. (1980). Approved lists of bacterial names. Int J Syst Bacteriol 30, 225-420.

Skerman, V. B. D., McGowan, V. \& Sneath, P. H. A. (editors) (1989). Approved Lists of Bacterial Names (Amended Edition). Washington, DC: American Society for Microbiology. 